\title{
Species Status of Hanseniaspora guilliermondii Pijper
}

\author{
SALLY A. MEYER, RUTH E. BROWN, AND MAUDY T. SMITH \\ American Type Culture Collection, Rockville, Maryland 20852; and Centraalbureau voor Schimmelcultures, \\ Laboratory of Microbiology, University of Technology, Delft, The Netherlands
}

\begin{abstract}
Selected yeasts presently classified as Hanseniaspora valbyensis Kloecker 1912 were examined for their physiological and morphological properties and their deoxyribonucleic acid (DNA) relatedness. The strain designated $H$. guilliermondii Pijper 1928 is herein recognized as a species separate from $H$. valbyensis. $H$. guilliermondii is distinguished from $H$. valbyensis by insignificant DNA reassociations, assimilation of 2 -keto-gluconate, growth at $37^{\circ} \mathrm{C}$, and formation of four ascospores per ascus.
\end{abstract}

The genus Hanseniaspora and its imperfect counterpart Kloeckera were extensively studied by Miller and Phaff in 1958 (8). These authors recognized three species in the genus Hanseniaspora, namely $H$. valbyensis, $H$. uvarum, and $H$. osmophila. The species $H$. guilliermondii described by Pijper (10) and H. melligeri described by Lodder (3) were not examined by Miller and Phaff themselves, but were taken as synonyms of $H$. valbyensis on the authority of Lodder and Kreger-van Rij (5). A strain described by Castelli as $H$. apuliensis was placed in synonymy with $H$. valbyensis (8). Kregervan $\mathrm{Rij}$ and Ahearn (2) in a study of the shape and structure of ascospores of $H$. uvarum and $H$. valbyensis stated that, among the synonyms of $H$. valbyensis, there is a distinct difference in maximum number of spores per ascus. The type strain $H$. valbyensis produces two hat-shaped ascospores, whereas $H$. quilliermondii and $H$. melligeri have four hat-shaped spores. Also, there is a difference in ability to grow at $37^{\circ} \mathrm{C}$. Strains identical with the last two species can grow at $37^{\circ} \mathrm{C}$, but strains with two spores can not. On the basis of these differences, Kreger-van Rij and Ahearn recognized that a separation of $H$. guilliermondii and $H$. melligeri from $H$. valbyensis might be justified.

The study of Nakase and Komagata (9) on the significance of deoxyribonucleic acid (DNA) base composition in the classification of the yeast genera Hanseniaspora and Kloeckera indicated that this suggestion was reasonable. A difference in guanine plus cytosine content between $H$. valbyensis and $H$. guilliermondii, being respectively 26.8 to $27.6 \mathrm{~mol} \%$ and 31.0 to $31.7 \mathrm{~mol} \%$, was found. To determine the correct classification of $H$. valbyensis and $H$. guilliermondii (including $H$. melligeri), the physiological and morphological properties and the DNA relatedness were examined.

\section{MATERIALS AND METHODS}

Organisms and morphological and physiological characteristics. The 10 cultures examined are listed in Table 1. The physiological properties were investigated by the methods in reference 4 . The assimilation tests were incubated on a shaker for 21 days. Ascosporulation was induced by incubation of the organisms on $5 \%$ malt extract agar.

DNA base composition and DNA reassociation. DNA was isolated and purified by the methods previously described (7). DNA base composition (expressed as the mean molar percent of the guanine and cytosine content [mol\% $\mathrm{G}+\mathrm{C}]$ ) was determined by the thermal denaturation method and formula $[\mathrm{mol} \%$ $\left.\mathrm{G}+\mathrm{C}=\left(T_{m}-69.3\right) / 0.41\right]$ of Marmur and Doty (6). DNA from the type culture of Candida parapsilosis (ATCC 22019) was used as the standard DNA $\left(T_{m}=85.9^{\circ} \mathrm{C}\right)$. The DNA-filter reassociation technique (1) was employed with modifications: DNA was extracted from cultures grown for $18 \mathrm{~h}$ (ATCC 10631 ) and $19 \mathrm{~h}$ (ATCC 10630) in 5\% glucose in yeast nitrogen base (Difco) supplemented with $2 \mu \mathrm{Ci}$ of [6$\left.{ }^{3} \mathrm{H}\right]$ uracil per $\mathrm{ml}$ and $2 \mu \mathrm{Ci}$ of $\left[8-{ }^{3} \mathrm{H}\right]$ adenine per $\mathrm{ml}$. DNA was sheared by passing the sample twice through a French mini-pressure cell at $20,000 \mathrm{lb} / \mathrm{in}^{2}$. Vials containing one 1-cm filter with approximately $25 \mu \mathrm{g}$ of immobilized single-stranded DNA were incubated with preincubation medium (PM) at $63^{\circ} \mathrm{C}$ for $2.5 \mathrm{~h}$. The PM was removed, and $1.0 \mu \mathrm{g}$ of fragmented, labeled DNA in $100 \mu \mathrm{l}$ of $2 \times \mathrm{SSC}$ (SSC = $0.15 \mathrm{M}$ sodium chloride and $0.015 \mathrm{M}$ sodium citrate $[\mathrm{pH} 7.0 \pm 0.2]$ ) was added to each vial. Incubation was continued at $63^{\circ} \mathrm{C}$ in a reciprocal water bath shaker at approximately 20 strokes per min for $13 \mathrm{~h}$. Filters were washed in $2 \times \mathrm{SSC}$ at $63^{\circ} \mathrm{C}$ and allowed to dry before the addition of scintillation fluid [Spectrafluor 2,5-diphenyloxazole-1,4-bis-(5-phenyloxazolyl)benzene (Amersham/Searle); prepared in toluene-Triton X-100 (2:1, vol/vol)].

Relatedness was calculated from the following equation: [(disintegrations per minute [dpm] of bound ${ }^{3} \mathrm{H}$-labeled DNA in the heterologous reaction)/(dpm of bound ${ }^{3} \mathrm{H}$-labeled DNA in the homologous reaction) $] \times 100=$ percentage of genetic relatedness. 


\section{RESULTS}

The physiological characteristics of the yeasts and the number of spores per ascus permitted their separation into two groups (Table 2).

Three strains (CBS 480, CBS 481, and CBS 6618 ) were similar to the type strain (CBS 479) of $H$. valbyensis. They failed to grow at $37^{\circ} \mathrm{C}$ and on 2-keto-gluconate. Two hat-shaped ascospores were formed.

Five cultures (CBS 95, CBS 466, CBS 2567, CBS 4378, and CBS 6619) were identical with the type strain (CBS 465) of $H$. guilliermondii.

These five cultures include the type strain (CBS 466) of $H$. melligeri. They all grow at $37^{\circ} \mathrm{C}$, utilize 2-keto-gluconate, and produce four hat-shaped spores.

The DNA base composition was determined for all 10 cultures (Table 3 ). The $\mathrm{G}+\mathrm{C}$ content spanned the narrow range of 29.5 to $33.4 \mathrm{~mol} \%$. The four cultures of $H$. valbyensis had $\mathrm{G}+\mathrm{C}$ values ranging from 29.5 to $30.0 \mathrm{~mol} \%$, whereas the six isolates grouped as $H$. guilliermondii exhibited a $\mathrm{G}+\mathrm{C}$ content between 33.2 and $33.4 \mathrm{~mol} \%$. To determine further the extent of relatedness between these yeasts, DNA reassociation experiments were done (Table 4). A

TABLE 1. List of cultures of $H$. valbyensis

\begin{tabular}{|c|c|}
\hline Designation $^{a}$ & Source \\
\hline CBS 479, ATCC 10631 & $\begin{array}{l}\text { Isolated from soil in Denmark; } \\
\text { type strain }\end{array}$ \\
\hline CBS 95 & From fermenting tomatoes \\
\hline CBS 465, ATCC 10630 & $\begin{array}{l}\text { Isolated from diseased nail; type } \\
\text { strain of } H \text {. guilliermondii }\end{array}$ \\
\hline CBS 466 & $\begin{array}{l}\text { Isolated from dates; type strain } \\
\text { of } H \text {. melligeri }\end{array}$ \\
\hline CBS 480 & $\begin{array}{l}\text { Obtained from } \mathrm{O} \text {. Winge, (Co- } \\
\text { penhagen) }\end{array}$ \\
\hline CBS 481, ATCC 2108 & $\begin{array}{l}\text { Received from the ATCC via W. } \\
\text { Lash Miller (Canada) }\end{array}$ \\
\hline CBS 2567 & Isolated from grape must \\
\hline CBS 4378 & Isolated from cecum of baboon \\
\hline CBS 6618 & $\begin{array}{l}\text { Isolated from tomato, received } \\
\text { from T. Nakase as AJ } 4810\end{array}$ \\
\hline CBS 6619 & $\begin{array}{l}\text { Received from } \mathrm{T} \text {. Nakase as AJ } \\
5176\end{array}$ \\
\hline
\end{tabular}

${ }^{a}$ ATCC, American Type Culture Collection; CBS, Centraalbureau voor Schimmelcultures.

TABLE 2. Salient characteristics to differentiate $H$. valbyensis and $H$. guilliermondii

\begin{tabular}{lcccc}
\hline Organism & $\begin{array}{c}\text { No. of } \\
\text { cultures } \\
\text { tested }^{a}\end{array}$ & $\begin{array}{c}2 \text {-Keto- } \\
\text { glucon- } \\
\text { ate }\end{array}$ & $\begin{array}{c}\text { Growth } \\
\text { at } 37^{\circ} \mathrm{C}\end{array}$ & $\begin{array}{c}\text { No. of } \\
\text { hat- } \\
\text { shaped } \\
\text { asco- } \\
\text { spores }\end{array}$ \\
\hline $\begin{array}{l}\text { H. valbyensis } \\
\text { H. guilliermondii }\end{array}$ & 4 & - & - & 2 \\
\hline
\end{tabular}

${ }^{a}$ Type strains are included. high degree of DNA reassociation (80 to 100\%) was demonstrated between the DNA from the type strain of $H$. valbyensis and strains physiologically grouped as $H$. valbyensis; $100 \%$ DNA reassociation was revealed between the type strain of $H$. guilliermondii and isolates grouped as $H$. guilliermondii. No significant DNA reassociation was expressed between DNA from the type strain of $H$. valbyensis and the strains grouped as $H$. guilliermondii, or between DNA from the type strain of $H$. guilliermondii and the strains grouped as $H$. valbyensis.

\section{DISCUSSION}

The data, in particular DNA reassociation, presented in this study show clearly that the

TABLE 3. DNA base composition

\begin{tabular}{lll}
\hline Organism & $T_{m}{ }^{a} \pm \mathrm{SD}^{b}$ & $\begin{array}{c}\text { Mol\% } \\
\mathrm{G}+\mathrm{C}\end{array}$ \\
\hline H. valbyensis & & \\
ATCC $10631^{c}$ & $81.6 \pm 0.08$ & 30.0 \\
CBS 480 & $81.4 \pm 0.13$ & 29.5 \\
CBS 481 & $81.4 \pm 0.09$ & 29.5 \\
CBS 6618 & $81.4 \pm 0.12$ & 29.5 \\
& & \\
H. guilliermondii & & \\
ATCC 10630 & $82.9 \pm 0.16$ & 33.2 \\
CBS 2567 & $82.9 \pm 0.10$ & 33.2 \\
CBS 4378 & $82.9 \pm 0.11$ & 33.2 \\
CBS 6619 & $82.9 \pm 0.10$ & 33.2 \\
CBS $\quad 95$ & $83.0 \pm 0.19$ & 33.4 \\
CBS 466 & $83.0 \pm 0.14$ & 33.4 \\
\hline
\end{tabular}

${ }^{a}$ Average of at least four thermal denaturation determinations.

${ }^{b} \mathrm{SD}$, Standard deviation.

c Type strain of species.

TABLE 4. DNA relatedness of $H$. valbyensis ATCC 10631 (CBS 479) and $H$. guilliermondii ATCC 10630 (CBS 465) to various strains of both species

\begin{tabular}{ccc}
\hline Source of unlabeled DNA & $\begin{array}{c}H . \text { valbyensis } \\
\text { ATCC 10631 }^{a}\end{array}$ & $\begin{array}{c}H . \text { guillier- } \\
\text { mondii ATCC } \\
10630^{a}\end{array}$ \\
\hline
\end{tabular}

H. valbyensis

ATCC $10631^{b} \quad(100)$

$\begin{array}{lll}\text { CBS } 481 & 100 & 16\end{array}$

$\begin{array}{lll}\text { CBS } 6618 & 81 & 16\end{array}$

$\begin{array}{lll}\text { CBS } 480 & 80 & 13\end{array}$

H. guilliermondii
ATCC $10630^{b}$

$\begin{array}{lll}\text { CBS } 95 & 22 & 100\end{array}$

CBS $466 \quad 14 \quad 100$

$\begin{array}{lll}\text { CBS } 2567 & 23 & 100\end{array}$

$\begin{array}{lll}\text { CBS } 4378 & 15 & 100\end{array}$

$\begin{array}{lll}\text { CBS } 6619 \quad 10 & 100\end{array}$

\footnotetext{
${ }^{a}$ Source of labeled DNA.

${ }^{b}$ Type strain.
} 
separation of $H$. guilliermondii from $H$. valbyensis as suggested by Kreger-van $\mathrm{Rij}$ and Ahearn (2) is sound. Since $H$. melligeri Lodder 1932 was described at a later date than $H$. guilliermondii (3), it is considered a synonym of this species. $H$. apuliensis, placed in synonymy with $H$. valbyensis by Miller and Phaff (8), was not examined in this study. Since the strain has lost its ability to sporulate, a phenomenon noted by many investigators $(5,8), H$. apuliensis will be examined in a later study on the perfect-imperfect relationship of Hanseniaspora and Kloeckera species.

\section{ACKNOWLEDGMENTS}

DNA studies performed at the American Type Culture Collection were supported in part by Public Health Service grant GM 19240-04 from the National Institute of General Medical Sciences.

\section{REPRINT REQUESTS}

Address reprint requests to: Dr. Sally A. Meyer, American Type Culture Collection, 12301 Parklawn Drive, Rockville, MD 20852.

\section{LITERATURE CITED}

1. Denhardt, D. T. 1966. A membrane filter technique for the detection of complementary DNA. Biochem. Biophys. Res. Commun. 23:641-646.

2. Kreger-van Rij, N. J. W., and D. G. Ahearn. 1968. Shape and structure of the ascospores of Hanseniaspora uvarum. Mycologia 60:604-612.

3. Lodder, J. 1932. Über einige durch das "Centraalbureau voor Schimmelcultures" neverworbene sporogene $\mathrm{He}$ fearten. Zentralbl. Bakteriol. Parasitenk. Infektionskr. Hyg. Abt. 2 86:227-253.

4. Lodder, J. (ed.). 1970. The yeasts - a taxonomic study. North Holland Publishing Co., Amsterdam.

5. Lodder, J., and N. J. W. Kreger-van Rij. 1952. The yeasts. A taxonomic study. North Holland Publishing Co., Amsterdam.

6. Marmur, J., and P. Doty. 1962. Determination of the base composition of deoxyribonucleic acid from its thermal denaturation temperature. J. Mol. Biol. 5:109-118.

7. Meyer, S. A., and H. J. Phaff. 1969. Deoxyribonucleic acid base composition in yeasts. J. Bacteriol. 97:5256.

8. Miller, M. W., and H. J. Phaff. 1958. A comparative study of the apiculate yeasts. Mycopathol. Mycol. Appl. 10:113-141.

9. Nakase, T., and K. Komagata. 1970. Significance of DNA base composition in the classification of yeast genera Hanseniaspora and Kloeckera. J. Gen. Appl. Microbiol. 16:241-250.

10. Pijper, A. 1928. Een nieuwe Hanseniaspora. Versl. Gewone vergadering Koninkl. Akad. Wetenschap. Afd. Natuurk. 37:868-871. 